\title{
Identification of Angiotensin I-converting enzyme Inhibitory Activities from traditional Mongolian fermented milk products
}

\author{
D.Bayarsaikhan ${ }^{1}$, Kohji YAMAKI ${ }^{2}$, G.Enkhtaivan ${ }^{3}$, Z.Ichinkhorloo ${ }^{4}$ \\ ${ }^{1}$ Shastin Central Hospital, Clinical Nutrition Departmentl, Mongolia \\ ${ }^{2}$ National Food Research Institute, Nutritional Function Laboratory, Japan, \\ ${ }^{3}$ Mongolian University of Science and Technology, \\ School of Food Engineering and Biotechnology, \\ ${ }^{4}$ Health Sciences University. School of Biomedicine
}

\begin{abstract}
Several angiotensen-converting enzyme (ACE) inhibitory peptites have been detected in milk products. There are many traditional milk products in Mongolia. For this study, some Mongolian milk products were collected, and the ACE inhibitory activities of these samples were tested; an active fraction was found in aaruul made from mare's milk. After purification by dialysis and HPLC, the active fractions were isolated. The molecular weight of the active component was $362.05 \mathrm{M}$, as determined by mass spectrometry. An authentic standard was used to determine the $\mathrm{IC}_{50}$ value of the inhibitory activity. From 5'-GMP is not much higher than that of the active peptide in sour milk and some flavonoids. However, this is the first report that shows that $5^{\prime}$-GMP inhibits ACE activity. These results will provide useful information for the development of hypertension therapy agents.
\end{abstract}

Keywords: traditional Mongolian milk product, angiotensin-converting enzyme,

5 -guanosine monophosphate

\section{Introduction}

$\Lambda$ ngiotensin I-converting enzyme (ACE) is one of the vasopressor principle. ACE convert angiotensin I to angiotensin II, that has a vasopressor action, in the rennin-angiotensin system and also inactivates bradykinin that is in an antihypertensive peptide. Recently, modification of the conventional ACE inhibition assay procedure has been requested because of the use of harmful organic solvent such as ethyl acetate for the extraction of hippuric acid cleaved from Hippuryl-His-Leu by ACE and its complicated procedure.

Fermented milk products, in addition to providing both energy and nutrients, are an excellent source of bioactive peptides. Numerous peptides with bioactive properties have been isolated from fermented dairy products. These include antibacterial, anticancer, immunomodulatory, mineralbinding, opioid and antihypertensive peptides. The dairy product making tradition, which has a 15,000 years of history in the region was a known skill for its ancient dwellers. Milk is sacred in Mongolia where milk and milk products are staple foods and produced in greatabundance from over 30 million head. Though more than 100 regional varieties are produced, traditional products are broadly classified as fat or protein -based or fermented. The Protein-based products aaruul (dried curd) is made that thick aarts is put on the wooden panel and pressed by a weight and cut it by threads, knife, and scraper or crumpled up and dried up finally. It is a 
strong tasty, sour like acid and light brown colored.

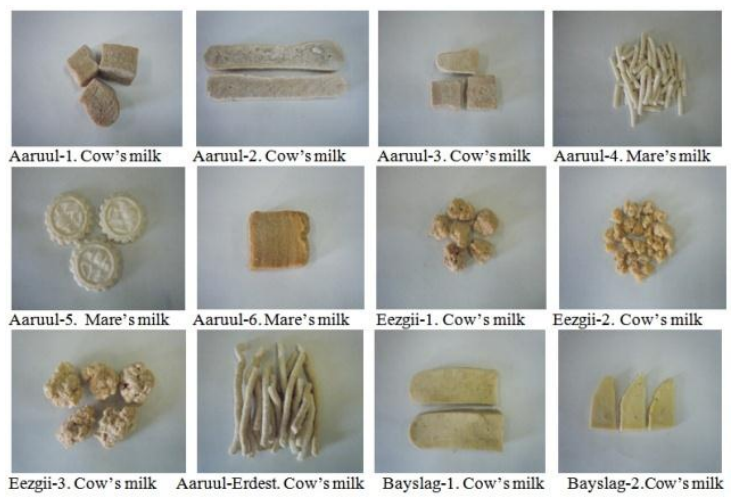

Mare's milk shows some structural and functional peculiarities that make it more suitable for human nourishment than cow's milk. Mare's milk is rich in vitamins and combines rare elements of zinc, calcium, copper and cobalts. It contains hormone of 'acetylcholine' that restores cells of nervous system, improves blood circulation by enhancing the coronary activity and reduces high blood pressure. Cow's milk is suitable making diary products and also for daily consumption.

\section{Experimental}

Aaruul (Dried curd), eezgii, bayslag samples were collected from in the Arhangai, Bayankhongor region of Mongolia.

The ACE inhibitory activity was assayed using commercially available ACE kit $\mathrm{WST}^{\circledR}$ assay kit (Dojindo Co. LTD.) Briefly, diluted samples were put into the well of 96well microplate, and enzyme-working mixture was added to each well. After incubation for 60 min, indicator-working solution was added to each well. After $10 \mathrm{~min}$, the plates were read the absorbance at $450 \mathrm{~nm}$ with microplate reader. The $\mathrm{IC}_{50}$ value was defined as the concentration of ACE inhibitory sample required to inhibit $50 \%$ of the ACE activity under the above assay conditions and was determined by a regression analysis of ACE inhibition (\%) versus sample concentration. Ethanol content was quantified by the chemical oxidation method after microdistillation of the aaruul samples, which was performed by Ethanol kit.
Calculate the ACE inhibit activity (inhibition rate \%) using the following equation;

ACE inhibitory activity (inhibition rate $\%)=\left[\left(\mathrm{A}_{\text {blank1 } 1}-\mathrm{A}_{\text {sample }}\right) /\left(\mathrm{A}_{\text {blank1 } 1}-\mathrm{A}_{\text {blank } 2}\right)\right] \mathrm{x} 100$

Blank 1: positive control (without ACE inhibition), blank 2: reagent blank

\begin{tabular}{|c|c|c|c|}
\hline Solution & Samples & Blank-1 & Blank-2 \\
\hline Sample solution & $20 \mu \mathrm{L}$ & - & - \\
\hline Deionized water & - & $20 \mu \mathrm{L}$ & $40 \mu \mathrm{L}$ \\
\hline Substrate buffer & $20 \mu \mathrm{L}$ & $20 \mu \mathrm{L}$ & $20 \mu \mathrm{L}$ \\
\hline $\begin{array}{c}\text { Enzyme working } \\
\text { Solution }\end{array}$ & $20 \mu \mathrm{L}$ & $20 \mu \mathrm{L}$ & - \\
\hline \multicolumn{4}{|c|}{$37^{0} \mathrm{C} 60 \mathrm{~min}$} \\
\hline $\begin{array}{l}\text { Indicator } \\
\text { Working } \\
\text { Solution }\end{array}$ & $200 \mu \mathrm{L}$ & $200 \mu \mathrm{L}$ & $200 \mu \mathrm{L}$ \\
\hline \multicolumn{4}{|c|}{ Room temparature. 10 min } \\
\hline \multicolumn{4}{|c|}{$450 \mathrm{~nm}$ with a microplate reader } \\
\hline
\end{tabular}

If the color of the sample solution is strong, substract the absorbance of the sample blank, that is prepared by sample solution $(10 \mu \mathrm{l})$ and deionized water $(100 \mu \mathrm{l})$, from that of the sample $\left(\mathrm{A}_{\text {sample }}\right)$ per each sample.

The concentration $(\mathrm{mg} / \mathrm{mL}$ or $\mu \mathrm{M})$ that inhibited $50 \%$ of ACE activity $\left(\mathrm{IC}_{50}\right)$ was determined by regression analysis of ACE inhibition (\%)versus peptide concentration in duplicate.

\section{Results and Discussion}

The ACE inhibitory activity of aaruul, eezgii was not affected by ACE preincubation. The ACE inhibitory activity of aaruul makes it commercially attractive in the future as a health-enhancing ingredient in the production of functional foods. The results of IC 50 values are shown in Table 1. Aaruul is a type of coagulated milk, eezgii is a kind of cottage cheese, while byaslag is a mild cheese, and all are produced I Mongolia. The $\mathrm{IC}_{50}$ values of aaruul samples ranged between 2.59 and 5.30 $\mathrm{mg} / \mathrm{ml}$, while the $\mathrm{IC}_{50}$ of eezgii was between 4.82 and $28.04 \mathrm{mg} / \mathrm{ml}$, and the $\mathrm{IC}_{50}$ values of the byaslag samples ranged from 123.37 to $141.47 \mathrm{mg} / \mathrm{mL}$. It has been previously reported that many peptides in sour milk have strong ACE inhibitory activity. 
Table 1. Angiotensin- converting enzyme inhibitory activity of Mongolian traditional milk products Extracts.

\begin{tabular}{|c|c|c|}
\hline Sample & Origin & $\mathbf{I C}_{\mathbf{5 0}}(\mathbf{m g} / \mathbf{m L})$ \\
\hline Aaruul-1 & Cow & 2.59 \\
\hline Aaruul-2 & Cow & 5.30 \\
\hline Aaruul-3 & Cow & 4.27 \\
\hline Aaruul-4 & Mare & 4.83 \\
\hline Aaruul-5 & Mare & 4.02 \\
\hline Aaruul-6 & Mare & 3.21 \\
\hline Eezgii-1 & Cow & 28.04 \\
\hline Eezgii-2 & Cow & 4.82 \\
\hline Eezgii-3 & Cow & 10.23 \\
\hline Byaslag-1 & Cow & 123.37 \\
\hline Byaslag-2 & Cow & 141.47 \\
\hline
\end{tabular}

Our present results demonstrated that aaruul has high ACE inhibitory activity. Figure 1 shows the results of the collective $\mathrm{IC}_{50}$ value between the different types of milk products were compared.

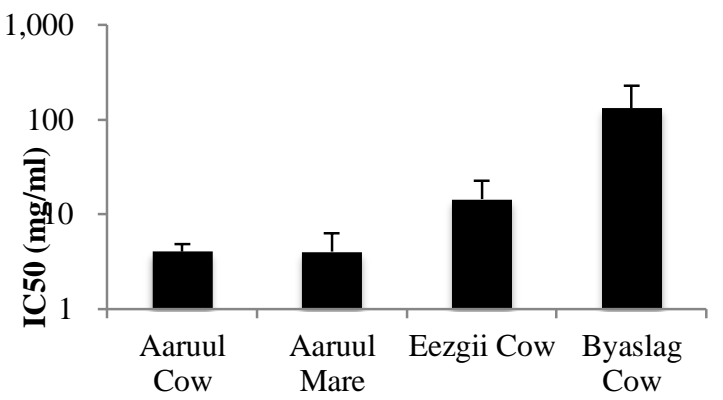

Fig.1. ACE inhibitory activities of various types in Mongolian traditional milk products.

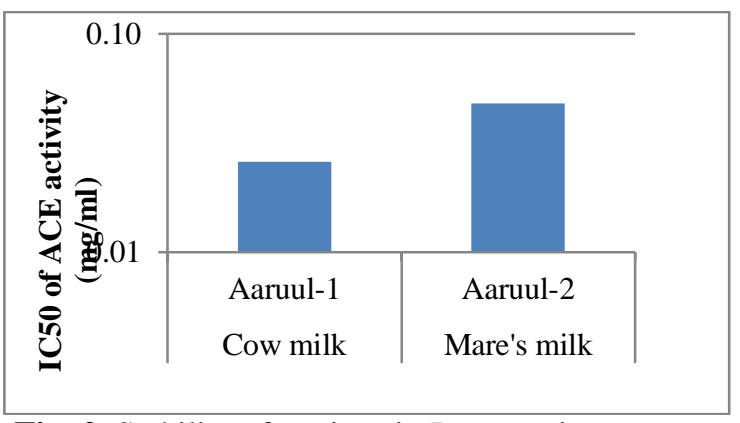

Fig. 2. Stability of angitensin I-converting enzyme (ACE) activity from aaruul (cow's milk, mare's milk)

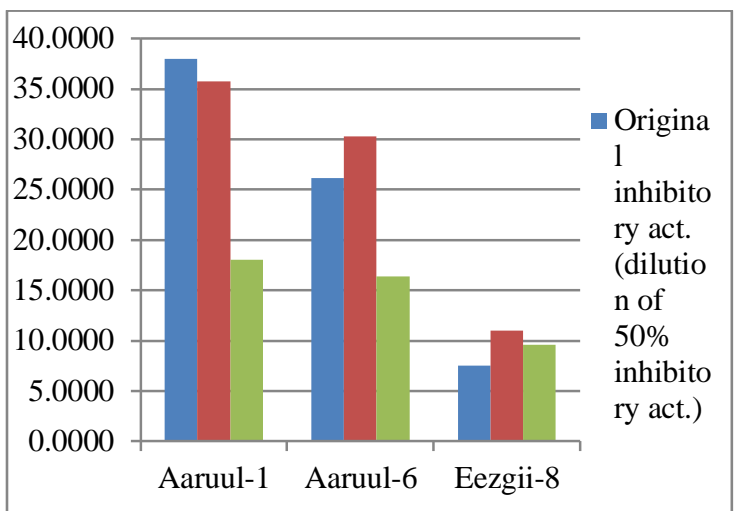

Fig.3. The ACE inhibitory activity between theoriginal and the treatments (relative ACE inhibitory index $=50 \%$ inhibitory concentration

There are many types of fermented milk products in Mongolia. Therefore, differences in the IC 50 value between the different types of milk products were compared. The relatively higher $\mathrm{IC}_{50}$ values $(4.02 \pm 0.81$ [mean \pm standard deviation] $\mathrm{mg} / \mathrm{mL}$ ) were found in the aaruul (mare) group. Aaruul (cow) showed almost a similar inhibitory activity, at $4.05 \pm 1.37 \mathrm{mg} / \mathrm{mL}$, whereas that of eezgii (cow) was $14.36 \pm 12.15 \mathrm{mg} / \mathrm{mL}$. The lowest $\mathrm{IC}_{50}(132.42 \pm 12.80 \mathrm{mg} / \mathrm{mL})$ was found in byaslag (cow).

\section{References}

1. Damdinsuren, L. Batshukh, Ts. Narangerel, Ch. Enkhtuul, Ts. (2004). Milk, Dairy Products Microbiology 24.

2. Tsetseg.B, (Feb 2004) The Central Asia and Mongolia Bioresources and Biosecurity Network: Mongolian Traditional Milk Products and their Microorganisms 47.

3. Okamoto. A, Hanagata.H, Matsumoto,E, Kawamura. Y, Koizumi. Y, and Yanagida.F, (1995) Angiotensin I Converting Enzyme Inhibitory Activities of Various Fermented Foods Bioscience 59:1147-1149.

4. Chen.Y, Wang.Z, Chen. X, Liu, Zhang. H. and Sun.T. (2010) Identification of angiotensin I-converting enzyme inhibitory peptides from koumiss, a traditional fermented mare's milk Journal of Dairy Science 93:884-892. 
5. Gomez-Ruiz.J.A., Ramos.M, and Recio.I, (2007). Identificatin of novel angiotensinconverting enzyme- inhibitory peptites from ovine milk proteins by CE-MS and chromatographic techniques. Electrophoresis, 28, 4202-4211.

6. Lam, Le H. Shimamura. T, S.Manabe, Ishiyama. M.. and Ukeda. H. (2008). Assay of angiotensin I-converting enzyme-inhibiting activity based on the detection of 3-hydroxybutyrate with water-soluble tetrazolium salt. Anal Sci, 24, 1057-1060.
7. Bayarsaikhan.D, Mayumi OhnishiKameyama, Nobuya Shirai, Yoko Takahashi and Kohji Yamaki. (2011) Inhibition of Angiotensin- converting Enzyme by Components of Traditional Mongolian Fermented Milk Products. Food Sci.Technol.Res., 17(6), 567.

8. Yamaki, Kohji and Mori, Yutaka, Evaluation of alpha.-glucosidase inhibitory activity in colored foods: a trial using slope factors of regression curves. (in Japanese) Nippon Shokuhin Kagaku Kogaku Kaishi, 53(4), 229-231. (2006) 